\title{
REGRESI PROBIT UNTUK ANALISIS VARIABEL-VARIABEL YANG MEMPENGARUHI PERCERAIAN DI SULAWESI TENGAH
}

\author{
Nur'eni $^{1}$, Lilies Handayani² \\ 1,2 Program Studi Statistika, Universitas Tadulako \\ e-mail: ${ }^{1}$ eniocy@yahoo.com, ${ }^{2}$ lilies.stath@gmail.com
}

\begin{abstract}
Abstrak
Sulawesi Tengah adalah salah satu Provinsi di Indonesia yang memiliki permasalahan dalam perceraian. Tingkat perceraian di Sulawesi Tengah pada tahun 2016 sebesar 2,44\%. Persentase tingkat perceraian di Sulawesi Tengah ini menjadi tingkat perceraian ketiga tertinggi di Indonesia. Pada penelitian ini diteliti faktor-faktor yang mempengaruhi kasus perceraian di Sulawesi Tengah. Metode yang digunakan adalah regresi probit biner dengan variabel respon adalah status perkawinan. Hasil penelitian menunjukkan bahwa variabel prediktor yang mempengaruhi perceraian secara signifikan di Provinsi Sulawesi Tengah adalah umur kawin pertama (X2) kategori 1 (18-21 tahun) dan kategori 2 ( $>21$ tahun), tingkat pendidikan (X3) kategori 1 (SD) dan kategori 4 (di atas SMA), daerah tempat tinggal (X4) kategori 1 (kota) dan jumlah pengeluaran rumah tangga (X6) dengan tingkat ketepatan klasifikasi model sebesar $99,2 \%$.
\end{abstract}

Kata kunci: regresi probit biner, perceraian, status perkawinan, ketepatan klasifikasi

\begin{abstract}
Central Sulawesi is one of province in Indonesia which has divorce trouble. The divorce rate in Central Sulawesi in 2016 is 2,44\%, the third highest divorce rate in Indonesia. This research aimed the influence factors of divorce cases in Central Sulawesi by using binary probit regression with the respon variable is marriage status. The result shows that the predictor variable which influence the divorce in Central Sulawesi are age of first marriage (X2) with age category 18-21 years and over 21 years, education level (X3) with elementary school and over high school category, habitation (X4) with urban categoryand household expanditure (X6) with the accuracy rate is $99,2 \%$.
\end{abstract}

Keywords: binary probit regression, divorce, marriage status, accuracy rate 


\section{PENDAHULUAN}

Demografi pertumbuhan penduduk Indonesia sangat dipengaruhi oleh adanya fertilitas. Perkawinan merupakan salah satu variabel yang mempengaruhi tinggi rendahnya tingkat fertilitas, sehingga secara tidak langsung mempengaruhi pertumbuhan penduduk. Perkawinan adalah ikatan lahir batin antara seorang pria dan seorang wanita sebagai suami istri dengan tujuan membentuk keluarga (rumah tangga) yang bahagia dan kekal berdasarkan ketuhanan Yang Maha Esa menurut UU Perkawinan No. 1 Tahun 1974. Perkawinan jika dilakukan pada umur yang "tepat" akan membawa kebahagian bagi keluarga dan pasangan (suami dan istri) yang menjalankan perkawinan tersebut. Perkawinan yang dilakukan pada usia yang terlalu muda (dini) akan membawa banyak konsekuensi pada pasangan, antara lain adalah kesehatan, pendidikan, dan ekonomi. Pada kesehatan khususnya dalam hal kejiwaan, dimana perkawinan yang dilakukan pada usia dini akan lebih mudah berakhir dengan kegagalan karena ketiadaan kesiapan mental menghadapi dinamika kehidupan berumah tangga (Dariyo, 2004).

Perceraian merupakan suatu peristiwa perpisahan secara resmi antara pasangan suami istri dan mereka berketetapan untuk tidak menjalankan tugas dan kewajiban sebagai suami istri. Mereka tidak lagi hidup dan tinggal serumah bersama, karena tidak ada ikatan yang resmi. Mereka yang telah bercerai tetapi belum memiliki anak, maka perpisahan tidak menimbulkan dampak traumatis terhadap psikologis anak-anak. Namun mereka yang telah memiliki keturunan, tentu saja perceraian menimbulkan masalah psiko-emosional bagi anak-anak (Dariyo, 2004). Menurut para ahli, seperti Nakamura (1990), Turner \& Helms (1995), Sudarto \& Wirawan (2001), terdapat beberapa faktor penyebab perceraian yaitu a) kekerasan verbal, b) masalah ekonomi, c) keterlibatan dalam perjudian, d)keterlibatan dalam penyalahgunaan minuman keras, e) perselingkuhan.
Perceraian merupakan salah satu masalah yang dihadapi oleh negara. Di Indonesia perceraian merupakan masalah yang penting untuk diatasi agar rumah tangga yang dijalani rukun dan damai. Menurut Badan Pusat Statistik (BPS, 2015; BPS, 2016) tingkat perceraian di Indonesia pada tahun 2015 sebesar 1,91\% dan pada tahun 2016 meningkat sebesar 1,93\%.

Sulawesi Tengah adalah salah satu Provinsi di Indonesia yang juga memiliki permasalahan dengan perceraian. Menurut Badan Pusat Statistik (BPS) tingkat perceraian di Sulawesi Tengah tahun 2016 sebesar 2,44\%, mengalami kenaikan dibanding tingkat perceraian pada tahun 2015 sebesar 1,97\%. Persentase perceraian di Sulawesi Tengah ini menjadi tingkat perceraian ketiga tertinggi setelah Nusa Tenggara Barat dan Kalimantan Selatan. Sehingga perlu dilakukan penelitian mengenai variabel-variabel yang mempengaruhi perceraian di Provinsi Sulawesi Tengah.

Analisis regresi dapat digunakan untuk menjelaskan variabel yang mempengaruhi perceraian di Provinsi Sulawesi Tengah. Analisis regresi merupakan metode analisis data yang menggambarkan hubungan sebab akibat antara variabel respon dan variabel prediktor. Jika variabel responnya berskala interval atau ratio, maka digunakan regresi linear. Analisis statistik yang dapat menjelaskan hubungan antara variabel respon dan variabel prediktor dimana variabel respon berupa data kualitatif atau kategori yaitu model logit dan model probit (Gujarati, 2004). Namun terdapat perbedaan dari kedua metode tersebut yaitu link function dan interpretasi model. Metode regresi probit merupakan metode yang menggunakan link function distribusi normal dengan interpretasi model menggunakan nilai efek marginal yang merupakan kelebihan dari regresi probit, sedangkan metode regresi logistik menggunakan link function distribusi logistik dan interpretasi model menggunakan nilai odds ratio (Masitoh \& Ratnasari, 2016). 
Penelitian sebelumnya yang berkaitan dengan perceraian dilakukan oleh Tresia pada tahun 2006 di wilayah Sumbar. Penelitian tersebut menggunakan metode regresi logistik. Diperoleh kesimpulan bahwa variabel yang berpengaruh signifikan terhadap perceraian adalah tingkat pendidikan, jenis pekerjaan, pendapatan, dan jumlah anak. Penelitian yang berkaitan dengan perceraian juga dilakukan oleh Riduan pada tahun 1998 dengan menggunakan model gabungan (logistik dan piecewice proportional hazard) diperoleh hasil bahwa variabel yang berpengaruh secara signifikan terhadap perceraian adalah kehadiran anak, umur kawin pertama, selisih umur dan perbedaan pendidikan. Berdasarkan teori di atas maka penelitian ini bertujuan untuk menerapkan metode regresi probit biner untuk mengetahui variabel apa saja yang berpengaruh terhadap kasus perceraian di Provinsi Sulawesi Tengah.

\section{METODOLOGI}

\section{Landasan Teori}

Regresi probit biner adalah metode regresi yang digunakan untuk menganalisis variabel dependen yang bersifat kualitatif dan beberapa variabel independen yang bersifat kualitatif, kuantitatif, atau gabungan dari kualitatif dan kuantitatif dengan pendekatan CDF (cumulative distribution function) distribusi normal (Gujarati, 2004). Model regesi probit biner adalah sebagai berikut :

$$
\boldsymbol{Y}^{*}=\boldsymbol{\beta}^{T} \boldsymbol{x}_{i}+\varepsilon
$$

dimana $\boldsymbol{Y}^{*}$ merupakan vektor variabel respon diskrit, $\boldsymbol{\beta}$ merupakan vektor parameter koefisien dengan $\boldsymbol{\beta}=$ $\left[\beta_{0}, \beta_{1}, \beta_{2}, \ldots, \beta_{p}\right]^{T}, \boldsymbol{x}$ merupakan vektor variabel prediktor dengan $\boldsymbol{x}=\left[1, x_{1}\right.$, $\left.x_{2}, \ldots, x_{p}\right]^{T}, \quad \varepsilon$ merupakan error yang diasumsikan berdistribusi $N(0,1)$ (Greene, 2008).

Model probit untuk $Y=0$ adalah probabilitas gagal $=q\left(x_{i}\right)$ :

$$
P(Y=0 \mid \boldsymbol{x})=\Phi\left(\gamma-\boldsymbol{\beta}^{\boldsymbol{T}} \boldsymbol{x}_{i}\right)=q\left(\boldsymbol{x}_{i}\right)
$$

Sedangkan model probit $Y=$ 1 adalah probabilitas sukses $=p\left(x_{i}\right)$ :

$$
\begin{aligned}
& P(Y=1 \mid \boldsymbol{x})=1-q\left(\boldsymbol{x}_{i}\right)=p\left(\boldsymbol{x}_{i}\right) \\
& \text { dimana } \quad \Phi\left(\gamma-\boldsymbol{\beta}^{\boldsymbol{T}} \boldsymbol{x}_{i}\right) \text { merupakan }
\end{aligned}
$$
fungsi distribusi kumulatif distribusi normal

\begin{tabular}{|c|c|c|c|}
\hline Simbol & Nama Variabel & Kategori & Skala Data \\
\hline \multirow{2}{*}{ Y } & \multirow{2}{*}{ Status perkawinan } & 0 : cerai hidup & \multirow{2}{*}{ Nominal } \\
\hline & & $1:$ kawin & \\
\hline \multirow{2}{*}{$\mathrm{X}_{1}$} & \multirow{2}{*}{ Status bekerja } & $0:$ tidak bekerja & \multirow{2}{*}{ Nominal } \\
\hline & & 1 : bekerja & \\
\hline \multirow{3}{*}{$\mathrm{X}_{2}$} & \multirow{3}{*}{ Umur kawin pertama } & $0:<18$ tahun & \multirow{3}{*}{ Ordinal } \\
\hline & & $1: 18-21$ tahun & \\
\hline & & $2:>21$ tahun & \\
\hline \multirow{5}{*}{$\mathrm{X}_{3}$} & \multirow{5}{*}{ Tingkat pendidikan } & 0 : tidak memiliki ijazah & \multirow{5}{*}{ Ordinal } \\
\hline & & $1: \mathrm{SD}$ & \\
\hline & & $2:$ SMP & \\
\hline & & $3:$ SMA & \\
\hline & & $4:$ di atas SMA & \\
\hline \multirow{2}{*}{$\mathrm{X}_{4}$} & \multirow{2}{*}{ Daerah tempat tinggal } & $0:$ desa & \multirow{2}{*}{ Nominal } \\
\hline & & $1:$ kota & \\
\hline \multirow{2}{*}{$\mathrm{X}_{5}$} & \multirow{2}{*}{ Status kepemilikan anak } & $0:$ belum memiliki anak & \multirow{2}{*}{ Nominal } \\
\hline & & $1:$ memiliki anak & \\
\hline $\mathrm{X}_{6}$ & Jumlah pengeluaran rumah tangga & - & Rasio \\
\hline
\end{tabular}
dengan rumus sebagai berikut :

$$
\Phi(x)=\int_{-\infty}^{x} \frac{1}{\sqrt{2 \pi}} \exp \left(-\frac{x^{2}}{2}\right) d x
$$

Tabel 1. Variabel Respon dan Variabel Prediktor 
Interpretasi model regresi probit biner tidak berdasarkan nilai koefisien model akan tetapi menggunakan efek marginal. Efek marginal menyatakan besarnya pengaruh tiap variabel prediktor yang signifikan terhadap probabilitas tiap kategori pada variabel respon dengan rumus sebagai berikut :

$$
\begin{gathered}
\frac{\partial P=\left(Y=0 \mid x_{i}\right)}{\partial \boldsymbol{x}_{i}}=-\phi\left(\gamma-\boldsymbol{\beta}^{\boldsymbol{T}} \boldsymbol{x}_{i}\right) \boldsymbol{\beta} \\
\frac{\partial P=\left(Y=1 \mid \boldsymbol{x}_{i}\right)}{\partial \boldsymbol{x}_{i}}=\phi\left(\gamma-\boldsymbol{\beta}^{\boldsymbol{T}} \boldsymbol{x}_{i}\right) \boldsymbol{\beta}
\end{gathered}
$$

(Greene, 2008).

\section{Metode Analisis}

Penelitian ini menggunakan data sekunder yang berasal dari Survei Sosial Ekonomi Nasional (SUSENAS) Provinsi Sulawesi Tengah tahun 2016. Pada Tabel 1 merupakan variabel-variabel yang digunakan sebagai variabel respon (Y) dan variabel-variabel prediktor (X) yang digunakan dalam penelitian.

Analisis pada penelitian ini dilakukan dengan menggunakan aplikasi R dan SPSS. Adapun tahapan pemodelan variabelvariabel yang mempengaruhi kasus perceraian menggunakan metode regresi probit biner dengan langkah-langkah sebagai berikut :

1. Membuat model regresi probit biner dengan meregresikan variabel status perkawinan (Y) dengan variabel $\mathrm{X}_{1}$ hingga $\mathrm{X}_{6}$ dimana parameter model diestimasi dengan menggunakan metode MLE (Maximum Likelihood Estimation)

2. Menguji signifikansi parameter secara serentak dengan statistik uji $G^{2}$ pada persamaan berikut :

$$
\begin{aligned}
G^{2} & =-2 \ln \left[\frac{L(\widehat{\omega})}{L(\widehat{\Omega})}\right] \\
& =2 \ln L(\widehat{\Omega})-2 \ln L(\widehat{\omega})
\end{aligned}
$$

Daerah penolakan dari statistik uji $G^{2}$ adalah tolak $\mathrm{H}_{0}$ jika nilai $G^{2}>$ $\chi_{(d b ; \alpha)}^{2}$ dimana $\mathrm{db}$ adalah derajat bebas atau $p$-value $<\alpha$. (Hosmer \& Lemeshow, 2000).

3. Jika didapatkan kesimpulan bahwa minimal terdapat satu variabel prediktor yang signifikan maka dilakukan uji parsial dengan statistik uji Wald pada persamaan :

$$
W_{j}=\frac{\widehat{\beta}_{J}}{S E\left(\widehat{\beta}_{J}\right)}
$$

Uji Wald memiliki daerah penolakan yaitu nilai $W$ dibandingkan dengan $\mathrm{Z}_{\text {tabel }}$ pada taraf signifikan $\alpha$ yang digunakan. Jika $|W|>Z_{\alpha / 2}$ atau $p$-value $<\alpha$. maka diputuskan untuk tolak $\mathrm{H}_{0}$ (Hosmer \& Lemeshow, 2000).

4. Menguji kesesuaian model regresi probit biner dengan statistik uji Deviance yang ditunjukkan oleh persamaan :

$$
\begin{aligned}
D= & -2 \sum_{i=1}^{n}\left[y_{i} \ln \left(\frac{\widehat{P}_{l}}{y_{i}}\right)\right. \\
& \left.+\left(1-y_{i}\right) \ln \left(\frac{1-\widehat{P}_{l}}{1-y_{i}}\right)\right]
\end{aligned}
$$

Keputusan $\mathrm{H}_{0}$ ditolak yaitu jika nilai $D>\chi_{(d b ; \alpha)}^{2}$ atau $p$-value $<\alpha$ (Hosmer $\&$ Lemeshow, 2000).

5. Melakukan evaluasi ketepatan klasifikasi model yang dilakukan dengan melihat peluang kesalahan klasifikasi model atau APER (Apparent Error Rate), formula untuk menghitung ketepatan klasifikasi model regresi probit biner dengan persamaan :

$$
1-A P E R=1-\left(\frac{n_{12}+n_{21}}{N}\right) \times 100 \%
$$

6. Menarik kesimpulan dari hasil penelitian

\section{HASIL DAN PEMBAHASAN}

Model regresi probit biner pada penelitian ini dibentuk melalui variabel respon Y (status perkawinan) yang bersifat kualitatif dengan dua kategori yaitu cerai hidup dan kawin, sedangkan variabel prediktor $\mathrm{X}$ yang digunakan untuk pemodelan regresi probit biner adalah status bekerja $\left(\mathrm{X}_{1}\right)$, umur kawin pertama $\left(\mathrm{X}_{2}\right)$, tingkat pendidikan $\left(\mathrm{X}_{3}\right)$, daerah tempat tinggal $\left(\mathrm{X}_{4}\right)$, status kepemilikan anak $\left(\mathrm{X}_{5}\right)$ dan jumlah pengeluaran rumah tangga $\left(\mathrm{X}_{6}\right)$.

Langkah pertama untuk melakukan pemodelan dengan metode probit biner adalah melalukan uji signifikansi parameter secara serentak. Pengujian ini bertujuan untuk mengetahui setidaknya terdapat satu variabel prediktor yang signifikan terhadap 
model dengan hipotesis $\mathrm{H}_{0}: \beta_{1}=\beta_{2}=$ $\cdots=\beta_{6}=0$ dan $\mathrm{H}_{1}$ : minimal ada satu $\beta_{j} \neq 0$. Uji yang digunakan untuk menguji signifikansi model secara serentak menggunakan uji rasio likelihood, hasil yang diperoleh adalah sebagai berikut :

\section{Metode Analisis}

Metode analisis yang digunakan dalam penelitian ini adalah analisis deskriptif dan analisis inferensia. Analisis deskriptif untuk mengetahui gambaran karakteristik anak penyandang disabilitas berdasarkan status partisipasi sekolahnya. Sedangkan analisis inferensia untuk menganalisis variabel-variabel yang memengaruhi dan kecenderungan berpartisipasi sekolah anak penyandang disabilitas. Analisis inferensia yang digunakan dalam penelitian ini adalah analisis multilevel regresi logistik biner dua level (bilevel regresi logistik biner). Level satu untuk tingkat individu dan level dua untuk tingkat provinsi. Menurut Hox (2010) analisis multilevel merupakan analisis yang digunakan untuk mengatasi masalah data dengan struktur hirarki. Model multilevel yang digunakan adalah model multilevel dengan random intercept karena diasumsikan bahwa pengaruh variabel bebas setiap kelompok adalah sama. Analisis multilevel regresi logistik biner digunakan karena variabel respons memiliki dua kategori yaitu anak penyandang disabilitas yang tidak bersekolah $(\mathrm{y}=0)$ dan anak penyandang disabilitas yang bersekolah $(\mathrm{y}=1)$.

Tahapan analisis diawali dengan uji kebebasan Chi-square dan uji U MannWhitney. Uji ini bertujuan untuk mengetahui variabel-variabel penjelas yang signifikan berhubungan dengan variabel partisipasi sekolah anak penyandang disabilitas untuk analisis bilevel regresi logistik biner. Kemudian melakukan pengujian signifikansi random effect dengan Likelihood Ratio Test untuk mengetahui apakah model multilevel regresi logistik biner lebih cocok digunakan daripada model regresi logistik biner satu level. Selanjutnya melakukan penghitungan variasi antar unit di level-2 menggunakan nilai Intraclass Corelation Coefficient (ICC).

Lalu dilakukan pengujian simultan yang bertujuan untuk mengetahui pengaruh seluruh variabel penjelas secara bersamasama terhadap partisipasi sekolah anak penyandang disabilitas. Jika pengujian parameter secara simultan memberikan kesimpulan bahwa terdapat paling sedikit satu variabel penjelas yang memengaruhi partisipasi sekolah anak penyandang disabilitas, maka tahapan selanjutnya menguji variabel penjelas secara parsial. Pengujian parsial digunakan untuk mengetahui variabel penjelas yang signifikan memengaruhi partisipasi sekolah anak penyandang disabilitas secara parsial. Setelah mengetahui variabel-variabel yang signifikan memengaruhi partisipasi sekolah anak penyandang disabilitas, tahap selanjutnya adalah menginterpretasikan nilai Odds Ratio (OR).

\section{HASIL DAN PEMBAHASAN}

Model regresi probit biner pada penelitian ini dibentuk melalui variabel respon Y (status perkawinan) yang bersifat kualitatif dengan dua kategori yaitu cerai hidup dan kawin, sedangkan variabel prediktor $\mathrm{X}$ yang digunakan untuk pemodelan regresi probit biner adalah status bekerja $\left(\mathrm{X}_{1}\right)$, umur kawin pertama $\left(\mathrm{X}_{2}\right)$, tingkat pendidikan $\left(\mathrm{X}_{3}\right)$, daerah tempat tinggal $\left(\mathrm{X}_{4}\right)$, status kepemilikan anak $\left(\mathrm{X}_{5}\right)$ dan jumlah pengeluaran rumah tangga $\left(\mathrm{X}_{6}\right)$.

Langkah pertama untuk melakukan pemodelan dengan metode probit biner adalah melalukan uji signifikansi parameter secara serentak. Pengujian ini bertujuan untuk mengetahui setidaknya terdapat satu variabel prediktor yang signifikan terhadap model dengan hipotesis $\mathrm{H}_{0}: \beta_{1}=\beta_{2}=$ $\cdots=\beta_{6}=0$ dan $\mathrm{H}_{1}$ : minimal ada satu $\beta_{j} \neq 0$. Uji yang digunakan untuk menguji signifikansi model secara serentak menggunakan uji rasio likelihood, hasil yang diperoleh adalah seperti pada Tabel 2 .

Berdasarkan tabel 2, hasil pengujian signifikansi parameter secara serentak menunjukkan bahwa nilai $G^{2}$ yang dihasilkan sebesar 65,529 dengan p-value 
Tabel 2. Uji Serentak Model Regresi Probit Linier

\begin{tabular}{|c|c|c|c|}
\hline Statistik Uji & Chi-Square & p-value & Kesimpulan \\
\hline$G^{2}$ & 65,529 & 0,000 & Tolak $\mathrm{H}_{0}$ \\
\hline
\end{tabular}

Tabel 3. Uji Parsial Model Regresi Probit Linier

\begin{tabular}{|l|c|c|c|c|}
\hline \multicolumn{1}{|c|}{ Prediktor } & Koefisien Regresi & SE & $W$ & P-value \\
\hline Konstanta & 0,325339 & 0,146011 & 2,23 & 0,026 \\
\hline$X_{1}$ (status bekerja) & 0,114305 & 0,0747391 & 1,53 & 0,126 \\
\hline 1 (bekerja) & 0,194059 & 0,0972509 & 2,00 & $0,046^{*}$ \\
\hline$X_{2}$ (umur kawin pertama) & 0,264884 & 0,0989808 & 2,68 & $0,007^{*}$ \\
\hline 1 (18-21 tahun) & 0,360575 & 0,0989029 & 3,65 & $0,000^{*}$ \\
\hline 2 (> 21 tahun) & 0,107861 & 0,140483 & 0,77 & 0,443 \\
\hline$X_{3}$ (tingkat pendidikan) & 0,204419 & 0,109184 & 1,87 & 0,061 \\
\hline 1 (SD) & 0,361750 & 0,155663 & 2,32 & $0,020^{*}$ \\
\hline 2 (SMP) & 0,199568 & 0,0782641 & 2,55 & $0,011^{*}$ \\
\hline 3 (SMA) & $-0,0532595$ & 0.0734891 & $-0,72$ & 0,469 \\
\hline 4 (di atas SMA) & $-0,0000003$ & 0,0000001 & $-4,87$ & $0,016^{*}$ \\
\hline$X_{4}$ (daerah tempat tinggal) & 1 (kota) &
\end{tabular}

sebesar 0,000 dengan $\alpha$ yang digunakan sebesar 0,05 . Karena $p$-value $(0,000)$ lebih kecil dari $\alpha(0,05)$ sehingga keputusan yang diambil adalah tolak H0. Dengan demikian dapat disimpulkan bahwa pada regresi probit biner dengan tingkat kepercayaan $95 \%$ minimal ada satu parameter yang signifikan pada model. Selanjutnya dilakukan pengujian parameter secara parsial yang hasilnya dapat dilihat pada tabel 3.

Pengujian signifikansi parameter parsial dilakukan untuk mengetahui variabel-variabel prediktor mana saja yang signifikan terhadap model dengan hipotesis $\mathrm{H}_{0}: \beta_{j}=0$ dan $\mathrm{H}_{1}: \beta_{j} \neq 0$ untuk $j=$ $1,2, \ldots, 6$. Uji parsial dilakukan dengan statistik uji Wald. Dari tabel di atas, diketahui bahwa nilai mutlak statistik uji $W$ pada variabel prediktor $\mathrm{X}_{2}$ (umur kawin pertama) kategori 1 (18-21 tahun) dan kategori 2 (> 21 tahun), $\mathrm{X}_{3}$ (tingkat pendidikan) kategori 1 (SD) dan kategori 4 (di atas SMA), $\mathrm{X}_{4}$ (daerah tempat tinggal) kategori 1 (kota) dan $\mathrm{X}_{6}$ (jumlah pengeluaran rumah tangga) lebih besar dari nilai tabel $Z_{0,05 / 2}=1,96$ atau dapat dilihat dari nilai $p$-value pada masing-masing prediktor yang nilainya kurang dari $\alpha(0,05)$, sehingga keputusan yang diambil adalah tolak $\mathrm{H}_{0}$. Dengan demikian dapat disimpulkan bahwa variabel yang signifikan terhadap perceraian adalah $\mathrm{X}_{2}$ (umur kawin pertama) kategori 1 (18-21 tahun) dan kategori 2 (>21 tahun), $\mathrm{X}_{3}$ (tingkat pendidikan) kategori 1 (SD) dan kategori 4 (di atas SMA), $\mathrm{X}_{4}$ (daerah tempat tinggal) kategori 1 (kota) dan $\mathrm{X}_{6}$ (jumlah pengeluaran rumah tangga).

Berdasarkan pengujian signifikansi parameter secara parsial, maka dibentuk model regresi probit biner dengan menggunakan nilai koefisien regresi yang signifikan tersebut sebagai berikut :

$$
\begin{aligned}
y^{*}= & 0,325339+0,194059 \mathrm{X}_{2(1)}+ \\
& 0,264884 \mathrm{X}_{2(2)}+0,360575 \mathrm{X}_{3(1)}+ \\
& 0,361750 \mathrm{X}_{3(4)}+0,199568 \mathrm{X}_{4(1)}- \\
& 0,0000003 \mathrm{X}_{6}
\end{aligned}
$$

Dari model di atas dapat dihitung nilai prediksi probabilitas setiap variabel. 
Sehingga didapatkan persamaan probabilitas respoden yang masuk ke dalam kategori bercerai adalah sebagai berikut :

$$
\begin{aligned}
\mathrm{P}(\mathrm{y}=0 \mid \mathrm{x})= & \Phi(0,325339 \\
& +0,194059 \mathrm{X}_{2(1)} \\
& +0,264884 \mathrm{X}_{2(2)} \\
& +0,360575 \mathrm{X}_{3(1)} \\
& +0,361750 \mathrm{X}_{3(4)} \\
& +0,199568 \mathrm{X}_{4(1)} \\
& -0,0000003 \mathrm{X}_{6}
\end{aligned}
$$

Besar pengaruh variabel umur kawin pertama $\left(\mathrm{X}_{2}\right)$, tingkat pendidikan $\left(\mathrm{X}_{3}\right)$, daerah tempat tinggal $\left(\mathrm{X}_{4}\right)$ dan jumlah pengeluaran rumah tangga $\left(\mathrm{X}_{6}\right)$ dapat dilihat melalui nilai marginal effect. Pada responden pertama untuk data perceraian dihitung marginal effect untuk mengetahui besar pengaruh keempat variabel dalam menggolongkan responden pertama ke kategori $y=0$ atau kategori bercerai. Sebagai ilustrasi, karakteristik untuk responden pertama pada variabel $\mathrm{X}_{2}$ (umur kawin pertama) adalah kategori 1 (18-21 tahun), variabel $\mathrm{X}_{3}$ (tingkat pendidikan) yaitu kategori 1 (SD), variabel $\mathrm{X}_{4}$ (daerah tempat tinggal) yaitu kategori 1 (desa) dan variabel $\mathrm{X}_{6}$ (jumlah pengeluaran rumah tangga) sebesar Rp 754.595. Hasil perhitungan marginal effect adalah sebagai berikut :

1. Nilai marginal effect untuk variabel $\mathrm{X}_{2}$

$$
\begin{gathered}
\frac{\partial P=(Y=0 \mid x)}{\partial X_{2}}=-\phi\left(\gamma-\boldsymbol{\beta}^{\boldsymbol{T}} \boldsymbol{x}\right) \boldsymbol{\beta}_{\mathbf{2}}= \\
0,4724
\end{gathered}
$$

Nilai marginal effect variabel $\mathrm{X}_{2}$ (umur kawin pertama) adalah 0,4724. Hal ini menunjukkan bahwa jika variabel $\mathrm{X}_{2}$ (umur kawin pertama) berkategori 1 atau umur perkawinan pertamanya antara 18 sampai 21 tahun maka akan menaikkan kecenderungan responden pertama masuk kategori $y=0$ atau kategori bercerai sebesar 0,4724 atau $47,24 \%$.

2. Nilai marginal effect untuk variabel $\mathrm{X}_{3}$

$$
\begin{gathered}
\frac{\partial P=(Y=0 \mid x)}{\partial X_{3}}= \\
-\phi\left(\gamma-\boldsymbol{\beta}^{\boldsymbol{T}} \boldsymbol{x}\right) \boldsymbol{\beta}_{\mathbf{3}}= \\
0,8777
\end{gathered}
$$

Jika variabel $\mathrm{X}_{3}$ (tingkat pendidikan) berkategori 1 atau tingkat pendidikannya SD, maka variabel tersebut akan meningkatkan kecenderungan responden pertama terklasifikasikan ke dalam kategori bercerai sebesar 0,8777 atau $87,77 \%$.

3. Nilai marginal effect untuk variabel $\mathrm{X}_{4}$

$$
\begin{gathered}
\frac{\partial P=(Y=0 \mid \boldsymbol{x})}{\partial X_{4}}=- \\
0,4858
\end{gathered}
$$

Variabel $\mathrm{X}_{4}$ (daerah tempat tinggal) yang berkategori 1 atau daerah tempat tinggal berada di kota akan meningkatkan kecenderungan responden masuk pada ketegori bercerai adalah sebesar 0,4858 atau 48,58\%.

4. Nilai marginal effect untuk variabel $\mathrm{X}_{6}$

$$
\begin{gathered}
\frac{\partial P=(Y=0 \mid \boldsymbol{x})}{\partial X_{6}}=-\phi\left(\gamma-\boldsymbol{\beta}^{\boldsymbol{T}} \boldsymbol{x}\right) \boldsymbol{\beta}_{\mathbf{6}}= \\
-0,0000007
\end{gathered}
$$

Dari perhitungan marginal effect $\mathrm{X}_{6}$ (jumlah pengeluaran rumah tangga), diketahui bahwa dengan kenaikan jumlah pengeluaran rumah tangga satu satuan akan menurunkan responden pertama masuk ke kategori bercerai sebesar 0,0000007 atau 0,00007\%.

Selanjutnya dilakukan pengujian kesesuaian model guna mengetahui apakah terdapat perbedaan yang signifikan antara hasil pengamatan dengan hasil prediksi model, dengan hipotesis $\mathrm{H}_{0}$ : tidak terdapat perbedaan antara hasil observasi dengan hasil prediksi (model sesuai) dan $\mathrm{H}_{1}$ : terdapat perbedaan antara hasil observasi dengan hasil prediksi (model tidak sesuai). Uji yang digunakan dalam penelitian ini adalah uji Deviance. Hasil yang diperoleh adalah pada tabel 4.

Berdasarkan tabel 4, hasil pengujian signifikansi kesesuian model menunjukkan bahwa nilai Deviance yang dihasilkan sebesar 2091,82 dan p-value sebesar 0,004 dengan $\alpha$ yang digunakan yaitu 0,05 .

Tabel 4. Uji Kesesuaian Model

\begin{tabular}{|c|c|c|c|}
\hline Statistik Uji & Chi-Square & p-value & Kesimpulan \\
\hline Deviance & 2091,82 & 0,004 & Tolak $\mathrm{H}_{0}$ \\
\hline
\end{tabular}


Tabel 5. Klasifikasi Model Regresi Probit Biner

\begin{tabular}{|c|c|c|c|}
\hline \multirow{2}{*}{ Kelompok Aktual } & \multicolumn{2}{|c|}{ Kelompok Prediksi } & \multirow{2}{*}{ Total } \\
\cline { 2 - 3 } & $\boldsymbol{y = 0}$ & $\boldsymbol{y}=\mathbf{1}$ & \\
\hline $\boldsymbol{y}=\mathbf{0}$ & 459 & 12 & 471 \\
\hline $\boldsymbol{y}=\mathbf{1}$ & 4 & 1525 & 1529 \\
\hline Total & 463 & 1537 & 2000 \\
\hline
\end{tabular}

Karena $\quad p$-value $\quad(0,004)<\alpha(0,05)$ sehingga keputusan yang diambil adalah tolak $\mathrm{H}_{0}$. Dengan demikian dapat disimpulkan bahwa terdapat perbedaan antara hasil observasi dengan hasil prediksi (model tidak sesuai).

Selanjutnya akan dibentuk tabel ketepatan klasifikasi atau confusion matrix yang digunakan untuk menggambarkan ukuran ketepatan antara data aktual dan data prediksi. Berikut adalah hasil pengelompokkan data aktual dengan data prediksi.

Berdasarkan tabel 5 dapat dihitung nilai persentase ketepatan klasifikasi dengan nilai APER yaitu :

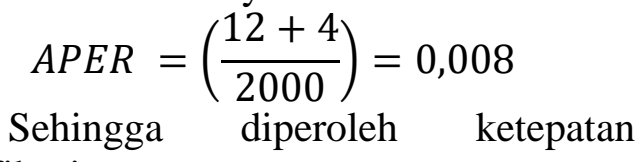
klasifikasi :

$$
(1-A P E R) \times 100 \%=99,2 \%
$$

Berdasarkan perhitungan yang diperoleh menunjukkan bahwa model regresi probit biner memiliki kemampuan mengklasifikasikan pengamatan dengan benar sebesar 99,2\%. Hal ini menunjukkan bahwa model regresi probit yang dibentuk sangat baik dalam mengklasifikasikan kasus perceraian di Provinsi Sulawesi Tengah berdasarkan variable-variabel yang berpengaruh.

\section{KESIMPULAN}

Berdasarkan hasil dan pembahasan yang telah dilakukan sebelumnya, maka dapat diperoleh kesimpulan bahwa berdasarkan model regresi probit biner yang dibentuk menghasilkan empat variabel yang signifikan terhadap kasus perceraian di Provinsi Sulawesi Tengah yaitu : X2 (umur kawin pertama) kategori 1 (18-21 tahun) dan kategori 2 (> 21 tahun), X3 (tingkat pendidikan) kategori 1 (SD) dan kategori 4 (di atas SMA), X4 (daerah tempat tinggal) kategori 1 (kota) dan X6 (jumlah pengeluaran rumah tangga). Hal ini dapat menjadi bahan pertimbangan bagi pemerintah dan masyarakat agar lebih memperhatikan faktor-faktor yang berpengaruh tersebut sehingga kasus percerain di Provinsi Sulawesi Tengah dapat diminimalisir.

\section{DAFTAR PUSTAKA}

Badan Pusat Statistik [BPS]. 2015. Statistik Kesejahteraan Rakyat Indonesia. Jakarta: BPS Indonesia.

Badan Pusat Statistik [BPS]. 2016. Statistik Kesejahteraan Rakyat Indonesia. Jakarta: BPS Indonesia.

Dariyo, A. 2004. Memahami Psikologi Perceraian dalam Kehidupan Keluarga. Jurnal Psikologi. Jakarta: Universitas Indonusa Esa Unggul.

Greene, W. H. 2008. Econometrics Analysis $\left(6^{\text {th }}\right.$ Edition). New Jersey: Pretince Hall, Inc.

Gujarati, D. 2004. Basic Econometrics (4 ${ }^{\text {th }}$ Edition). New York: The McGrawHill.

Hosmer, D and Lemeshow, S. 2000. Applied Logistic Regression $\left(2^{\text {nd }}\right.$ Edition). New Jersey: John Wiley \& Sons.

Masitoh, F dan Ratnasari, V. 2016. Pemodelan Status Ketahanan Pangan di Provinsi Jawa Timur dengan Pendekatan Metode Regresi Probit Biner. Jurnal Institut Teknologi Sepuluh Nopember. Surabaya: ITS.

Nakamura, H. 1990. Perceraian Orang Jawa. Yogyakarta: UGM Press.

Riduan. 1998. Penerapan Model Gabungan (Logistik dan Piecewise Proportional Hazard). Tesis.: Bogor: IPB. 
Sudarto, L dan Wirawan, H. E. 2001. Penghayatan Makna Hidup Perempuan Bercerai. Jurnal Ilmiah Psikologi. Jakarta: Universitas Tarumanegara.

Turner, J. S and Helms, D. B. 1995. LifeSpan Development (5 $5^{\text {th }}$ Edition). New York: Holt, Rinehart \& Winston.

Tresia, D. 2006. Faktor-faktor yang Mempengaruhi Perceraian di Sumatera Barat. Jurnal Universitas Andalas. Padang: Universitas Andalas. 
